\title{
Supernumerary chromosomes in the pufferfish Sphoeroides spengleri - First occurrence in marine Teleostean Tetraodontiformes fish
}

\author{
Anderson Luis Alves ${ }^{1}$, Fábio Porto-Foresti ${ }^{2}$, Claudio Oliveira ${ }^{3}$ and Fausto Foresti ${ }^{3}$ \\ ${ }^{1}$ Departamento de Parasitologia, Instituto de Biologia, Universidade Estadual de Campinas, \\ Campinas, SP, Brazil. \\ ${ }^{2}$ Departamento de Ciências Biológicas, Faculdade de Ciências, Universidade Estadual Paulista, \\ Campus de Bauru, Bauru, SP, Brazil. \\ ${ }^{3}$ Departamento de Morfologia, Instituto de Biociências, Universidade Estadual Paulista, \\ Campus de Botucatu, Botucatu, SP, Brazil.
}

\begin{abstract}
Cytogenetic analyses carried out in eight specimens of Sphoeroides spengleri revealed the presence of $2 \mathrm{n}=46$ chromosomes (20 M/SM and 26 ST/A). Besides the standard karyotypical set, the presence of B microchromosomes was observed in two individuals, ranging from 0 to 2 microchromosomes per cell. A karyotype composed by $2 n=46$ chromosomes with occurrence of $\mathrm{M}$ and SM chromosomes is considered basal for the species from the clade comprising the families Tetraodontidae, Balistidae, and Diodontidae, although it represents a derived condition for the order Tetraodontiformes, whose basal karyotype would be composed by $2 n=48$ acrocentric chromosomes. The occurrence of B microchromosomes in marine Tetraodontiformes fish was not known, and this represents the first report of such a chromosomal type.
\end{abstract}

Key words: B chromosome, pufferfish, Sphoeroides spengleri.

Received: October 11, 2006; Accepted: May 22, 2007.

The order Tetraodontiformes comprises nearly 340 species, divided into five families (Nelson, 1994). Although typically marine, a few species are found in freshwaters, such as Colomesus asellus in the Amazon Basin, and are regarded as freshwater invaders (Figueiredo and Menezes, 2000). Phylogenetically, the Tetraodontiformes are considered one of the most derived clades within Teleostei, representing a sister group of Perciformes (Lauder and Liem, 1983). The genus Sphoeroides (Tetraodontidae) is regarded as basal for the family (Arai, 1983; Brum et al., 1995; Brum, 2000), evidencing its importance for evolutionary studies. Sphoeroides spengleri, one of the six species of the genus, presents a small body size of about $15 \mathrm{~cm}$, and it is widespread from Massachusetts (USA) to the southeastern Brazilian shore (Figueiredo and Menezes, 2000).

Pufferfishes present the smallest DNA content per cell amongst vertebrates, as Tetraodon fluviatilis that has $0.39 \mathrm{pg}$ (Hinegardner and Rosen, 1972). Such a compact

Send correspondence to Fábio Porto-Foresti. Departamento de Ciências Biológicas, Faculdade de Ciências, Universidade Estadual Paulista, Campus de Bauru, 17033-360 Bauru, SP, Brazil. E-mail: fpforesti@fc.unesp.br. genome in pufferfishes was followed by the occurrence of the smallest chromosomes so far described in vertebrates, constraining refined cytogenetical analyses (Fischer et al., 2000; Brum and Mota, 2002). The diploid number in Tetraodontiformes ranges from $2 \mathrm{n}=28$ in Canthigaster coronata (Arai, 1983) to $2 \mathrm{n}=52$ in Chilomycterus spinosus (Brum, 2000), suggesting that this group is not karyotypically conserved. The diploid number of $2 n=46$ observed in the Sphoeroides species previously surveyed (Brum and Mota, 2002) is considered the basal karyotype for the more derived Tetraodontiformes: Tetraodontidae, Balistidae, and Diodontidae (Arai, 1983; Brum, 2000; Galetti et al., 2006).

The occurrence of supernumerary chromosomes in Neotropical fishes seems to be a common event in freshwater species, previously reported in 41 of the 921 analyzed species (Oliveira et al., 2000), characterized by the presence of B microchromosomes (Alves and Martins-Santos, 2002) or B macrochromosomes (Porto-Foresti et al., 1997). In about 81 Neotropical marine species analyzed so far, this chromosomal type was not observed in fishes from the family Tetraodontidae (Oliveira et al., 2000; Galetti et al., 2006). Therefore, aiming to increase the karyotype information in fishes from the family Tetraodontidae, specimens 
of $S$. spengleri from the northern coast of the State of São Paulo, Brazil, were cytogenetically analyzed.

The cytogenetic analyses were performed in eight specimens ( 3 females, 4 males, and 1 sex undetermined individual) of $S$. spengleri collected at Ubatuba Bay, São Paulo, Brazil. The specimens were identified and deposited in the fish collection of the Laboratório de Biologia e Genética de Peixes, LBP-UNESP, Botucatu, SP, Brazil. Chromosome preparations were obtained from gill and kidney tissues using the technique described by Foresti et al. (1993). Chromosome morphology was determined on the basis of arm ratio as proposed by Levan et al. (1964), and the chromosomes were classified as metacentric (M), submetacentric (SM), subtelocentric (ST), and acrocentric (A).

Our cytogenetical analysis showed that $S$. spengleri presents a diploid number equal to $2 \mathrm{n}=46$, with $20 \mathrm{M} / \mathrm{SM}$ chromosomes, and $26 \mathrm{ST} / \mathrm{A}$ chromosomes, without sexrelated differences (Figure 1). Two individuals of this species presented $\mathrm{B}$ microchromosomes, ranging from 0 to 2 (Figure 1). The diploid number of $2 \mathrm{n}=46$ chromosomes was observed in all species of the genus Sphoeroides so far analyzed, S. greeleyi (Brum et al., 1995), S. tyleri (Brum, 2000), and S. spengleri (Brum et al., 1995, present paper).

Although the diploid number is conserved in Sphoeroides species, the karyotypical macrostructure presents differences related to the number of metacentric and acrocentric chromosomes, useful for species identification. Such karyotypical differences are a result of successive chromosomal rearrangements, mainly pericentric inversions. The diploid number of $2 n=46$ is regarded as basal for the polyphyletic clade composed by Tetraodontidae, Balistidae, and Diodontidae. The species of this group present highly derived karyotypes for Tetraodontiformes, ranging from $2 \mathrm{n}=28$ in Canthigaster coronata (Arai, 1983) to $2 \mathrm{n}=52$ in Chilomycterus spinosus (Brum, 2000), characterizing it as the most karyotypically diverse group of marine teleosteans (Galetti et al., 2000; Galetti et al., 2006). According to Brum et al. (1995), these derived karyotypes might have arisen from Triacanthidae species, considered the basal group of Tetraodontiformes, which present primitive karyotypes composed of $2 n=48$ acrocentric chromosomes (Lauder and Liem, 1983).

The occurrence of supernumerary microchromosomes in Sphoeroides spengleri represents the first report of such a chromosomal type inmarine Tetraodontiformes fish. The absence of supernumerary chromosomes in this fish group could be important in the future to understand the probable origin of this type of chromosome in fishes. However, the group of marine fishes needs more cytogenetical studies to find new cases of supernumerary chromosomes. The occurrence of supernumerary chromosomes in S. spengleri reinforces the hypothesis that marine teleosteans do not represent a group that is highly karyotypically conserved, as previously thought. In addition, chromosomal polymorphisms and sex chromosomes have been
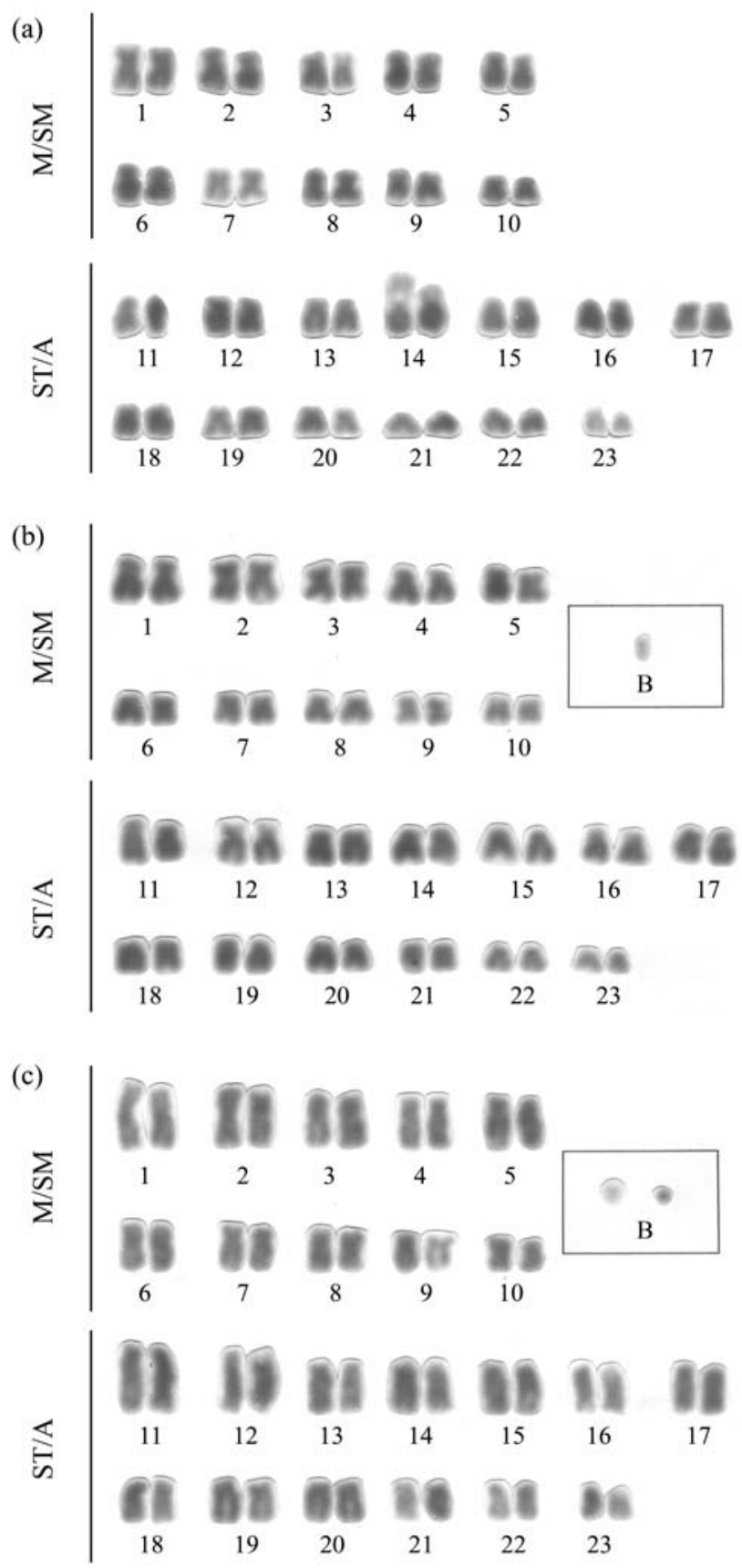

Figure 1 - Karyotype of Sphoeroides spengleri (Tetraodontidae) in (a). In (b) one B microchromosome is shown in detail, and in (c) two B microchromosomes are shown in detail.

identified in several marine fish species (Galetti et al., 2006).

The origin of such supernumerary chromosomes is controversial. A hypothesis for the origin of the B macrochromosome in Astyanax scabripinnis is a putative adaptative advantage determined by these chromosomes in individuals from high altitude (Néo et al., 2000) and inhabiting headwaters (Porto-Foresti et al., 1997). However, there is no adaptative hypothesis associated with $\mathrm{B}$ microchromosomes, and their low frequency might suggest a re- 
cent origin in freshwater fishes (Alves and Martins-Santos, 2002). Furthermore, the differences related to intraindividual frequency, morphology and size of supernumerary chromosomes among freshwater teleosteans suggest different origins of these chromosomes. Similar to freshwater teleosteans, the origin of supernumerary chromosomes amongst marine fishes is still unknown, but the origins of B microchromosomes in freshwater and marine fishes do not seem to be phylogenetically related, representing independent evolutionary pathways. However, further analyses in other species are required to the understanding of the origin of supernumerary chromosomes within this fish group.

\section{Acknowledgments}

The authors are grateful to Renato Devidé for technical assistance, and to Dr. Rogério Caetano da Costa (LABCAM, UNESP, Bauru, SP) for collecting the specimens. Funds supporting this study were provided by FAPESP, CAPES, and CNPq.

\section{References}

Alves AL and Martins-Santos I (2002) Cytogenetic studies in two populations of Astyanax scabripinnis with $2 \mathrm{n}=48$ chromosomes (Teleostei, Characidae). Cytologia 67:117-122.

Arai R (1983) Karyological and osteological approach to phylogenetic systematics of tetraodontiform fishes. Bull Natl Sci Mus Tokyo Ser A 9:175-210.

Brum MJI (2000) Cytogenetic studies in Tetraodontiforms Sphoeroides tyleri (Tetraodontidae) and Chilomycterus (Diodontidae) from Rio de Janeiro Coast, Brazil. Chromosome Sci 4:103-105.

Brum MJI and Mota LCG (2002) C-banding and nucleolar organizer regions of Sphoeroides greeley (Tetraodontidae, Tetraodontiformes). Caryologia 55:171-174.

Brum MJI, Oliveira CC and Galetti Jr PM (1995) Cytogenetic studies of Sphoeroides (Tetraodontidae, Pisces) along the Rio de Janeiro Coast. Cytologia 60:369-374.
Figueiredo JL and Menezes NA (2000) Manual de Peixes Marinhos do Sudeste do Brasil. VI Teleostei (5). Museu de Zoologia, São Paulo, 166 pp.

Fischer C, Ozouf-Costaz C, Crollius HR, Dasilva C, Jailon O, Borneau L, Bonillo C, Weissenbach J and Bernot H (2000) Karyotype and chromosome location of characteristic tandem repeats in the pufferfishe Tetraodon nigroviridis. Cytogent Cell Genet 88:50-55.

Foresti F, Oliveira C and Almeida-Toledo LF (1993) A method for chromosome preparations from large fish specimens using in vitro short-term treatment with colchicines. Experientia 49:810-813.

Galetti Jr PM, Aguilar CT and Molina WF (2000) An overview of marine fish cytogenetics. Hydrobiologia 420:55-62.

Galetti Jr PM, Molina WF, Affonso PRAM and Aguilar CT (2006) Assessing genetic diversity of Brazilian reef fishes by chromosomal and DNA markers. Genetica 126:161-177.

Hinegardner R and Rosen DE (1972) Cellular DNA content and evolution of teleostean fishes. Amer Nat 106:621-644.

Lauder GV and Liem KF (1983) The evolution and interrelationships of the Actinopterygean fishes. Bull Mus Comp Zool 150:95-197.

Levan A, Fredga K and Saindberg AA (1964) Nomenclature for centromeric position on chromosomes. Hereditas 52:201220.

Nelson JS (1994) Fishes of the World. 3rd ed. John Wiley \& Sons Inc, New York, 600 pp.

Néo DM, Bertollo LAC and Moreira-Filho O (2000) Morphological differentiation and possible origin of B chromosomes in natural brazilian population of Astyanax scabripinnis (Pisces, Characidae). Genetica 108:211-215.

Oliveira C, Almeida-Toledo LF and Foresti F (2000) Revisão dos estudos citogenéticos em peixes neotropicais de águas continentais. In: VIII Simposium de Citogenética e Genética de Peixes, 2000, Manaus.

Porto-Foresti F, Oliveira C, Maistro EL and Foresti F. (1997) Estimated frequency of B-chromosomes and population density of Astyanax scabripinnis paranae in a small stream. Braz J Genet 20:377-380.

Associate Editor: Pedro Manoel Galetti Junior

License information: This is an open-access article distributed under the terms of the Creative Commons Attribution License, which permits unrestricted use, distribution, and reproduction in any medium, provided the original work is properly cited. 